Editorial

\title{
Bio-filters Application for Treatment of Volatile Organic Compounds and Odor
}

\section{Roger Saint-Fort*}

Department of Environmental Science, Mount Royal University, Calgary, AB, Canada

*Corresponding author: Roger Saint-Fort, Ph.D., P. Ag, Environmental Chemist, Professor \& Chair, Environmental Science Department, Mount Royal University, Calgary, AB T3E6K6, Tel: (403) 440-6683, Fax: (403) 440-8558, E-mail: rsaintfort@mtroyal.ca

\section{Received Date: Dec 26, $2014 \quad$ Accepted Date: Jan 02, $2015 \quad$ Published Date: Jan 06, 2015}

Citation: Roger, S.F. Bio-filters Application for Treatment of Volatile Organic Compounds and Odor (2015) J Environ Health Sci 1(1): 9.

\section{Introduction}

Many anthropogenic sources of volatile organic compounds (VOCs) originated from industrial activities can be toxic as well as deadly to humans and detrimental to the environment. Biofiltration represents a cost effective and democratic technology that can be used for the control of biodegradable VOCs and offensive odour from air streams. Additionally, air bio-filtration can be used with soil vacuum extraction and air stripping of groundwater to treat VOCs extracted from those matrices during cleanup operation.

\section{Bio-filtration Operation}

The literature describes three biological types of systems for treating contaminated air streams. These are biotrickling filters, bioscrubbers and biofilters. The latter is the focus of this paper. Fundamentally, two main principles govern the bio-catalytic operation of a biofilter. Initial transfer of anthropogenic contaminants from the contaminated air feed to the support media, and the subsequent bio-catalyst to carbon dioxide, water, biomass, and other by-products. In a traditional biofilter system, microorganisms reside on the surface of the biofilter inert media to form a fixed-bio film bioreactor where the contaminant is bio-catalysed $^{[1]}$. Small quantities of nutrient primarily nitrogen and occasional irrigation of the system is required. The operation of a typical biofilter is depicted in Figure 1.

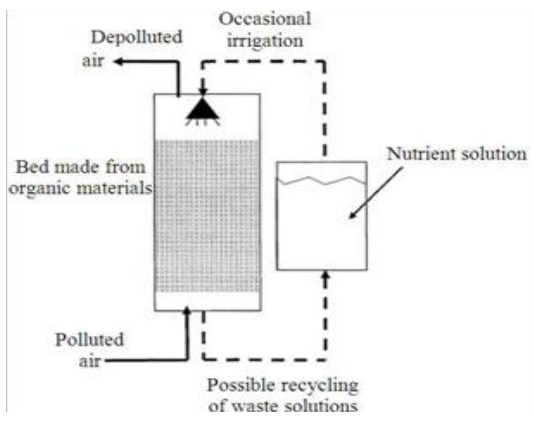

Figure 1. Schematic of a typical biofilter system according to Delhomenic and Heitz, 2005.

In biofiltration, the bio-catalytic degradation equation processes can be represented conceptually in Equations 1 and 2, respectively:
Contaminated air stream + Air Aerobic microbes $\mathrm{CO}_{2}+$ salt +

$\mathrm{H}_{2} \mathrm{O}+$ heat + biomass + by-products

Contaminated air stream $+\mathrm{CH}_{4}$ Anaerobic microbes $\mathrm{CO}_{2}+$

salt $+\mathrm{H}_{2} \mathrm{O}+$ biomass + by-products

\section{Performance Evaluation}

Three main parameters are considered in evaluating the performance of a biofiltration system, namely contaminant loading capacity (LC), elimination capacity (EC), and removal efficiency (RE). These can be represented mathematically in Equations 3 to 5 , respectively

$$
\begin{array}{ll}
\mathrm{LC}\left(\mathrm{g} \mathrm{m}^{-3} \mathrm{~h}^{-1}\right)=\left(\mathrm{C}_{\mathrm{g} \text {, inlet }} \times \mathrm{Q}\right) / \mathrm{V} & \text { (Eq.3) } \\
\left.\mathrm{EC}\left(\mathrm{g} \mathrm{m}^{-3} \mathrm{~h}^{-1}\right)=\left(\mathrm{C}_{\mathrm{g} \text {, inlet }}-\mathrm{C}_{\mathrm{g} \text {, effluent }}\right) \times \mathrm{Q}\right) / \mathrm{V} & \text { (Eq.4) } \\
\operatorname{RE}(\%)=\left\{\left(\mathrm{C}_{\mathrm{g} \text {, inlet }}-\mathrm{C}_{\mathrm{g} \text {, effluent }}\right) \times 100\right\} / \mathrm{C}_{\mathrm{g} \text {, inlet }} & \text { (Eq.5) }
\end{array}
$$

Several factors will impact on the operation of a biofilter. They include natural microorganisms acclimation time, feed flow rate, nutrient requirement, pressure drop, oxygen or methane requirements, $\mathrm{pH}$, temperature, moisture, empty bed residency time, concentration of the contaminant in feed stream, filter bed and maintenance frequency. The interactions of these governing factors will ultimately dictate the successful performance of the biofilter.

\section{Limitations of Biofiltration}

Although the application of biofilters to treat VOCs and odor control is relatively simple and green technology, it has some limitations and challenges as compared to other elimination techniques. The major demerits are (1) inability of the system to adapt to sudden loading stresses (2) extended acclimation requirement for the microbial population (3) acidification as a result of acid products accumulation (4) large footprint requirement.

\section{Reference:}

1. Delhomenic, M.C., Heit, M. Biofiltration of air: A review. (2005) Critical Revi Biotechnol 25(1-2): 53-72.

Copy rights: (C)2015 Roger, S.F. This is an Open access article distributed under the terms of Creative Commons Attribution 4.0 International License. 